\title{
Hubungan Pengetahuan dan Sikap dengan Perilaku Ibu Menghadapi Anak Berkebutuhan Khusus
}

\author{
Fanny Dameria, ${ }^{1}$ Elisabeth Isti Daryati, ${ }^{2}$ dan Sada Rasmada ${ }^{3}$ \\ 1,2,3Program Studi Keperawatan \\ Sekolah Tinggi Ilmu Kesehatan Sint Carolus \\ Salemba Raya No 41 Jakarta Pusat 10440 \\ Email :,fannydameria@,stik-sintcarolus.ac.id, ${ }^{1}$ elisabethdaryati@gmail.com,2 \\ sadarasmada@stik-sintcarolus.ac.id ${ }^{3}$
}

\begin{abstract}
Abstrak
Pendahuluan: Anak berkebutuhan khusus adalah anak yang secara signifikan berbeda dalam beberapa dimensi dari fungsi kemanusiaannya. Kurangnya penerimaan tentang kondisi anak dan kurangnya pengetahuan akan kebutuhan anak yang berkebutuhan khusus sering kali menyebabkan seseorang bersikap negatif terhadap anak tersebut.

Tujuan: Tujuan penelitian adalah mengetahui adakah hubungan antara pengetahuan dan sikap dengan perilaku ibu menghadapi anak retardasi mental.

Metode: Jenis penelitian ini adalah studi kuantitatif deangan desain korelasi deskriptif dan metode pendekatan cross sectional. Sampel dalam penelitian ini sebanyak $30 \mathrm{ibu}$ yang memiliki anak berkebutuhan khusus (retardasi mental) di SLBC Dian Grahita. Analisis data menggunakan chi-square.

Hasil: Hasil penelitian ini menunjukan ada hubungan pengetahuan ( $\mathrm{p}$ value $=0,03$ ) dan sikap ( $\mathrm{p}$ val$\mathrm{ue}=0,00)$ terhadap perilaku ibu menghadapi anak retardasi mental di SLBC Dian Grahita Jakarta.

Kesimpulan: Ada hubungan antara pengetahuan dengan perilaku ibu dalam menghadapi anak dengan retardasi mental.
\end{abstract}

Kata Kunci: pengetahuan, perilaku, retardasi mental, sikap

\section{Pendahuluan}

Anak retardasi mental disebut juga anak berkebutuhan khusus yang memiliki keterbelakangan mental. Anak retardasi mental yang sangat berat sering mengalami kesulitan dalam mengurus diri selayaknya anak normal.

\begin{abstract}
Introduction: Children with special needs are children who are significantly different in some dimensions of his humanitarian function. Lack of acceptance of the child's condition and the lack of knowledge of the needs of children who have special needs often cause someone to be negative towards the child.
\end{abstract}

Objective: The purpose of this study was to determine whether there is a relationship between knowledge and attitude with the behavior of mothers facing mental retardation children.

Method: This type of research is a quantitative study of and descriptive correlation design and cross-sectional approach methods. The samples in this study were as many as 30 mothers who had special needs children (mental retardation) at SLBC Dian Grahita. Data analysis with Chi-square

Results: The results of this study showed that there was a knowledge relationship $(p$-value $=0.03)$ and attitude ( $p$-value $=0.00$ ) to the behavior of the mother facing mental retardation child in Jakarta.

Conclusion: There is a relationship between knowledge and mother's behavior in dealing with children with mental retardation.

Keywords: knowledge, attitudes, mental retardation, behaviour

Anak ini memiliki kemampuan intelektual yang rendah sehingga mengalami keterbatasan dalam bidang keterampilan, komunikasi, perawatan diri, kegiatan sehari-hari, kesehatan, keselamatan dan akademis. ${ }^{1}$ Keterbatasan yang dimiliki anak ini perlu mendapatkan perhatian 
lebih dari orang tua. Orangtua perlu berusaha memberikan yang terbaik pada anak dengan meminta bantuan pada orang yang ahli dalam menanganinya.

Seseorang dengan retardasi mental memiliki intelegensi dibawah rata-rata sejak masa perkembangan dan ketidakmampuan dalam interaksi sosial. ${ }^{2}$ Keterbatasan intelektual dan fungsi adaptif yang ada merupakan hasil dari proses patologik di dalam otak. ${ }^{3}$ Gangguan patologik dalam otak ini dapat disebabkan oleh infeksi atau intoksikasi akibat dari dalam kandungan, gangguan metabolisme, pertumbuhan atau gizi kurang, akibat penyakit otak yang nyata, pengaruh prenatal yang tidak jelas dan prematuritas. ${ }^{4}$

Data WHO (2017) diperkirakan jumlah anak retardasi mental di Indonesia sebanyak 6,6 juta jiwa.5 Insiden tertinggi anak ini pada masa sekolah dengan puncak umur 10 sampai 14 tahun. Penyandang retardasi mental lebih banyak mengenai 1,5 kali pada laki-laki dibandingkan perempuan. ${ }^{6}$ Berdasarkan data dari Dinas Sosial pada tahun 2012 di Jawa Tengah terdapat penyandang retardasi mental sekitar 18,516 orang anak dan di Semarang jumlah anak yang mengalami retardasi mental 363 orang pada tahun 2014. Prevalensi retardasi mental di Jakarta 62.011 anak yang terbagi menjadi $60 \%$ berjenis kelamin laki-laki dan $40 \%$ berjenis perempuan. ${ }^{7}$

Berdasarkan Undang-Undang Pendidikan Nasional tahun 2012 dan Peraturan Pemerintah No.72 tahun 2012, bentuk pendidikan kelompok untuk anak dengan retardasi mental berupa sekolah-sekolah khusus yang disebut sekolah luar biasa (SLB) dan sekolah dasar luar biasa (SDLB). Pendidikan di SLB ini membantu melatih perkembangan anak dari segi pemikiran dan perilaku anak. Namun rangsangan pikiran dan perilaku ini perlu dilakukan secara kontinyu bukan hanya di sekolah tetapi juga di rumah.

Peran orangtua sangat dibutuhkan untuk mempertahankan kehidupan fisik anak dan meningkatkan kesehatannya. Orang tua harus memfasilitasi anak dan memberi kesempatan untuk melakukan kegiatan sejalan dengan tahapan perkembangannya dalam berperilaku sesuai dengan nilai agama dan budaya. ${ }^{8,9}$ Peran ini dapat berjalan dengan baik jika orangtua memiliki pengetahuan yang memadai tentang kondisi anak. Pengetahuan ibu tentang retardasi mental dapat membantu memahami kendala-kendala yang dialami anak. Ibu perlu memberikan perhatian khusus dan lebih peka dalam memberikan rangsangan emosi dan sosial agar kondisi anak juga semakin positif. 3,8 Hal ini sejalan dengan hasil riset yang menyatakan ibu yang memahami dan menyadari akan kelemahan anak retardasi mental merupakan faktor yang membantu perkembangannya di lingkungan. ${ }^{1,8}$ Penelitian Hafid menyatakan bahwa pengetahuan ibu tentang retardasi mental yang sangat minim, membuat orangtua tidak memahami dan menghadapi kendala yang akan muncul dalam keseharian anak. ${ }^{10,11}$ Hal ini dapat menjadi pemicu ada rasa tidak berdaya bahkan menyangkal kondisi anak retardasi mental, sehingga membuat orangtua pesimis di saat anak sulit ditangani. ${ }^{10}$

Ibu dengan anak retardasi mental sebagian besar mengalami syok, kecewa dan bersifat menolak. Sikap ini dan kebiasaan yang diterapkan oleh ibu dan keluarga dapat menunjukkan kecenderungan anak akan menjadi lebih rendah diri dan menarik diri pada lingkungan. Sikap yang dilakukan tersebut sebagai usaha melampiaskan kepuasan ibu. ${ }^{12}$ Ibu yang dapat menerima keadaan anak retardasi mental memiliki sikap bahwa anak tersebut sudah pemberian Tuhan dalam keluarga. Sikap ini biasanya disebabkan karena ibu mendapat dukungan sosial dan motivasi yang cukup dari lingkungan sekitar, seperti keluarga teman, dan orang-orang terdekat. Sikap penerimaan dan dukungan yang diterima ibu dapat membuat orangtua berhasil dalam menghadapi tantangan merawat anak dengan retardasi mental. Oleh karena itu dukungan dari keluarga sangat penting untuk membantu ibu mengembangkan kemampuannya sesuai dengan kapasitas yang dimiliki anak. ${ }^{8,13}$

Berdasarkan hal di atas, peneliti ingin mengetahui adakah hubungan antara pengetahuan dan sikap dengan perilaku ibu menghadapi anak retardasi mental.

\section{Metode}

Penelitian ini menggunakan jenis penelitian kuantitatif dengan rancangan cross sectional, dan desain korelasi deskriptif. Populasi dalam penelitian ini adalah ibu yang 
memiliki anak retardasi mental yang masih aktif disekolah SLB C Dian Grahita Jakarta dengan jumlah sampel 30. 17 Penelitian dilakukan di SLB C Dian Grahita Jakarta pada bulan Desember- Juli 2017/2018. Analisa data pada jenis penelitian kuantitatif meliputi analisa data univariat untuk mengetahui distribusi frekuensi dari tiap variabel dan analisa data bivariate menggunakan uji statistik Chisquare. ${ }^{18}$

\section{Hasil}

Analisa yang dilakukan memperoleh hasil sebagai berikut

Tabel 1. Distribusi Frekuensi Pengetahuan, Sikap dan Perilaku

\begin{tabular}{lrr} 
Pengetahuan & Frekuensi & \multicolumn{2}{c}{ Presentase } \\
\hline Kurang & 16 & $53,4 \%$ \\
Cukup & 7 & $23,3 \%$ \\
Baik & 7 & $23,3 \%$
\end{tabular}

\begin{tabular}{|c|c|c|c|}
\hline Sikap & Frekuensi & & Presentase \\
\hline Negatif & & 14 & $46,7 \%$ \\
\hline Positif & & 16 & $53,5 \%$ \\
\hline Perilaku & Frekuensi & & Presentase \\
\hline Negatif & & 15 & $50 \%$ \\
\hline Positif & & 15 & $50 \%$ \\
\hline Total & & 30 & $100 \%$ \\
\hline
\end{tabular}

Tabel 1. Menyajikan tingkat pengetahuan kurang sebanyak 16 reponden $(53,4 \%)$. Mayoritas ibu memiliki sikap positif dalam menghadapi anak retardasi mental di SLBC Dian Grahita ini, yaitu sebesar 53,3\%. Responden memiliki dapat dilihat 15 responden $(50,0 \%)$ memiliki perilaku yang positif dan 15 responden $(50,0 \%)$ memiliki perilaku yang negatif.

Tabel 2. Hubungan Pengetahuan dengan Perilaku Ibu dalam Menghadapi Anak Retardasi Mental

\section{Perilaku}

\begin{tabular}{cccccccc}
\hline \multirow{2}{*}{ Pengetahuan } & \multicolumn{2}{c}{ Negatif } & \multicolumn{2}{c}{ Positif } & \multicolumn{2}{c}{ Total } & P-Value \\
& N & \% & N & \% & N & \% & \\
Kurang & 12 & 75 & 4 & 25 & 16 & 100 & \\
\hline Cukup+Baik & 3 & 21,4 & 11 & 78,6 & 14 & 100 & 0,03 \\
\hline Total & 15 & 50 & 15 & 50 & 30 & 100 & \\
\hline
\end{tabular}

Tabel 2 menunjukkan bahwa hasil analisis statistik didapatkan $\mathrm{p}$ value $=0,03<\alpha=0,05$, dengan demikian dapat disimpulkan bahwa

ada hubungan antara pengetahuan dan perilaku ibu dalam menghadapi anak retardasi mental

Tabel 3. Hubungan Sikap dengan Perilaku Ibu dalam Menghadapi Anak Retardasi Mental

Perilaku

\begin{tabular}{cccccccc}
\hline \multirow{2}{*}{ Sikap } & \multicolumn{2}{c}{ Negatif } & \multicolumn{2}{c}{ Positif } & \multicolumn{2}{c}{ Total } & P-Value \\
& N & $\mathbf{\%}$ & N & \% & N & \% & \\
Kurang & 13 & 92,9 & 1 & 17,1 & 14 & 100 & \\
\hline Cukup+Baik & 2 & 12,5 & 14 & 87,5 & 16 & 100 & 0,03 \\
\hline Total & 15 & 50 & 15 & 50 & 30 & 100 & \\
\hline
\end{tabular}


Tabel 3 menunjukkan bahwa hasil analisis statistik didapatkan $\mathrm{p}$ value $=0,00<\alpha=0,05$, dengan demikian dapat disimpulkan bahwa ada hubungan antara sikap dan perilaku ibu dalam menghadapi anak retardasi mental.

\section{Pembahasan}

Hasil analisis dalam tabel 2 menunjukkan bahwa ada hubungan antara pengetahuan ibu dengan perilaku ibu dalam menghadapi anak dengan retardasi mental. Berdasarkan uji Chi square diperoleh nilai $\mathrm{p}$ sebesar 0,003 (p-Value $<0,005$ ). Ini berarti bahwa pengetahuan yang dimiliki ibu akan mempengaruhi perilaku ibu dalam menghadapi anak dengan retardasi mental. Semakin kurangnya tingkat pengetahuan yang dimiliki ibu tentang perilaku anak berkebutuhan khusus atau lebih spesifiknya anak retardasi mental akan berpeluang untuk melakukan perilaku yang negatif dalam menghadapi anak. Hasil penelitian ini sejalan dengan penelitian Zemmy E.L. yang menyatakan bahwa terdapat hubungan yang bermakna antara pengetahuan dengan perilaku ibu..$^{14}$

Pengetahuan adalah hasil tahu seseorang yang didapat melalui penginderaan mengunakan panca indera serta dipengaruhi oleh intensitas perhatian terhadap suatu objek tertentu.15 Hasil observasi peneliti di lingkungan sekolah peningkatan pengetahuan ibu dipengaruhi oleh taraf pendidikan yang mayoritas berpendidikan tinggi, usia rata-rata berada pada tahap usia dewasa menengah, pekerjaan sebagai PNS dan karyawan swasta. Hal-hal ini meningkatkan kemampuan seseorang untuk memperoleh informasi.selain dari adanya pertemuan-pertemuan antara orang tua dengan pihak yayasan yang membahas berbagai hal tentang masalah anak dengan retardasi mental. Upaya peningkatan pengetahuan oranng tua juga terus menerus dilakukan oleh guru-guru di yayasan tersebut dengan memberikan informasi aktivitas sehari-hari yang dilakukan anak di sekolah dan menganjurkan pada orang tua atau pengasuh untuk melibatkan anak dalam aktivitas sehari-hari seperti makan, berpakaian, melatih buang air besar/kecil.

Kebutuhan informasi yang sederhana sampai mendalam terkait anak retardasi mental cenderung akan meningkat jika individu mengalami secara langsung ketika merawat anak.11 Informasi itu dapat bersumber dari tenaga kesehatan (perawat, dokter), media massa, televisi, dan sesama teman yang mempunyai anak retardasi mental. Adanya informasi baru mengenai suatu hal yang berdekatan dengan diri seseorang akan mendapatkan perhatian lebih mendalam sehingga dapat memberikan landasan kognitif baru. ${ }^{19}$

Pengetahuan bagaimana cara menghadapi anak dan mengetahui apa yang akan dilakukan jika anak memberontak juga mempengaruhi perilaku positif yang ditunjukkan oleh ibu. Potts dan Mandleco menyatakan bahwa pengetahuan orang tua secara nyata akan kondisi anak retardasi mental dapat membantu bagaimana cara menghadapi anak dalam aktivitas sehari-hari. 11,14

Tabel 3 menunjukkan hasil analisis adanya hubungan antara sikap dengan perilaku ibu dalam menghadapi anak retardasi mental. Berdasarkan uji analisis dengan chi square didapat p-value $0,000(\alpha<0,5)$ disimpulkan bahwa ada hubungan bermakna antara sikap dengan perilaku ibu dalam menghadapi anak retardasi mental. Hal ini berarti sikap ibu yang kurang baik terhadap anak retardasi mental mempengaruhi terbentuknya perilaku negatif ibu dalam menangani anak sehari-hari. Hasil penelitian yang dilakukan Dewi A.S (2012) menunjukkan bahwa terdapat hubungan yang bermakna antara sikap dengan perilaku ibu dalam menghadapi anak retardasi mental dengan $(\mathrm{p}$-value $=0,000) .{ }^{16}$

Sikap merupakan kesiapan untuk beraksi terhadap objek di lingkungan tertentu sebagai suatu penghayatan terhadap objek .6,16 Proses pembentukan sikap dapat terjadi karena adanya rangsangan, seperti pengetahuan yang dimiliki ibu untuk merawat anak retardasi mental. Rangsangan tersebut menstimulus diri untuk memberi respon berupa sikap positif dan sikap negatif. Akhirnya sikap positif maupun sikap negatif tersebut akan diwujudkan dalam perilaku. ${ }^{20}$

Sikap yang baik dengan perilaku positif ibu menghadapi anak retardasi mental dapat disebabkan oleh beberapa faktor antara lain pengalaman pribadi dan pengaruh orang lain. Pengalaman pribadi maupun orang lain yang dipercaya akan membantu proses penerimaan ibu terhadap kondisi keterbatasan intelektual dan keterampilan anak sehari-hari. ${ }^{3,20}$ Ibu yang 
menyadari dan keadaan anak retardasi mental dapat menyesuaikan diri dengan kemampuan yang dimiliki anak. ${ }^{1,8,13}$ Kemampuan adaptasi ibu ini dapat dipengaruhi oleh dukungan keluarga, saudara dan lingkungan sekitarnya. ${ }^{9,11,13,20}$

\section{Kesimpulan}

Ada hubungan antara pengetahuan dengan perilaku ibu dalam menghadapi anak dengan retardasi mental. terdapat hubungan antara variabel pengetahuan dengan perilaku ibu. Sedangkan pada variabel lainnya, diperoleh hasil adanya hubungan antara sikap dengan perilaku ibu dalam menghadapi anak dengan retardasi mental. perlu terus meningkatkan pengetahuan berupa keterlibatan aktif ibu dalam perawatan anak secara lansung. Keterlibatan ibu ini dapat menjadi evaluasi strategi pengasuhan yang telah dilakukan sehari-hari sehingga dapat lebih optimal. Selain itu, sikap positif ibu dapat terus terjaga dengan dukungan dari keluarga, saudara dan lingkungan sekitar.

\section{Daftar Pustaka}

1. Utami, Y. Penyesuaian Diri dan Pola Asuh Orangtua yang memiliki Anak Retardasi Mental. Surakarta: Universitas Muhammadiyah Surakarta; 2009.

2. Sandra, M. Anak Cacat bukan kiamat; Metode Pembelajaran dan Terapi untuk Anak Berkebutuhan Khusus. Yogyakarta: Katahati; 2010.

3. Soemantri, S. Psikologi Anak Luar Biasa. Bandung : Refika Aditama; 2009.

4. Maramis. Catatan Ilmu Kedokteran Jiwa. Surabaya: Airlangga University press; 2009.

5. Suwarsi, A.A. Metode Penelitian Administrasi. Bandung: Alfabeta; 2016.

6. Muhith, Abdul. Pendidikan Keperawatan Jiwa Teori dan Aplikasi. Indonesia; 2015.

7. Siswanto, S. Manajemen Tenaga Kerja Indonesia. Jakarta: Bumiaksara; 2015.

8. Hockenberry, M. Wilson, D. Wong's nursing care of infants and children. Elsevier: USA; 2014.

9. Pujiastuti,U. Hubungan antara dukungan ayah, pengetahuan ibu tentang anak autis dan religiusitas (dimensi praktik agama) dengan penerimaan ibu terhadap anak auti. Eprints.ums.ac.id; 2014.

10. Hafid, I. Pengasuhan orang tua pada anak retardasi mental ringan. Skripsi. Universitas Ahmad Dahlan. Yogyakarta; 2011.
11. Potts,N.L. Mandleco, B.L. Pediatric nursing: Caring for children and their families. Delmar: Canada; 2012.

12. Santrock,J,W. Psikologi pendidikan kencana. Jakarta; 2010.

13. Semiun, Y. Kesehatan mental. Kanisius.: Yogyakarta; 2009.

14. Zemmy E.L. Hubungan pengetahuan keluarga dan tingkat retardasi mental dengan kemampuan merawat di SLB Negeri Unggaran; 2014.

15. Notoatmodjo, S. Metodologi Penelitian Kesehatan . Jakarta: Rineka Cipta; 2010.

16. Dewi A.S. Sikap orangtua terhadap anaknya yang menyandang retardasi mental di SLB Surya Wiyata Jawa Barat"; 2012.

17. Notoatmodjo, S. Metodologi penelitian dan kesehatan. Jakarta : Rineka cipta; 2012.

18. Susilo, W. Prinsip-prinsip biostatistik dan aplikasi SPSS pada ilmu keperawatan. Jakarta: In media; 2013.

19. Azwar, S. Metode Penelitian. Yogyakarta: Pustaka Pelajar; 2013.

20. Ramawati, D. Kemampuan perawatan diri anak tuagrahita berdasarkan faktor eksternal dan internal anak. Jakarta: Fakultas Ilmu Keperawatan Universitas Kristen Indonesia; 2012. 